\title{
The Directness Levels of Criticism: A Cross-Cultural Comparative Study of Korean and American Youtuber
}

\author{
Aan Anisah Agustini Safari \\ Master Program on Linguistics, Airlangga University, Surabaya, Indonesia \\ Email Correspondence: aanisahagustin9@gmail.com
}

\begin{abstract}
Background:
Abstract

Different countries may have different cultures that are influenced by their religion, traditions, or norms. These differences affect the way they speak, such as when they are commenting or giving opinions. Due to the way people express speech acts can be varied and lead to misinterpretation because of their differences, the researcher was intrigued to conduct this study.
\end{abstract}

Methodology:

This cross-cultural study was carried out to observe and compare the speech act of criticism between Korean and American YouTubers and to investigate the role of their cultural background in influencing the directness level they conveyed. First, the researcher selected three Korean Youtubers and Americans as well with food review content. Second, the researcher watched one video from each channel and took notes on every expression of criticism they used.

Findings:

The result of this study demonstrates that in American YouTubers speech, direct strategy emerges more frequently than the indirect one. Conversely, Korean YouTubers tend to use the indirect one. The finding also indicates that their speech behavior is related to their cultural norms, in which American culture encourages clear personal opinions, while Korean culture is a restraint to express their opinion or feeling clearly.

\section{Conclusion:}

Due to the considerable difference between Korean and American YouTuber speech, it can be concluded that culture takes a significant part in shaping one's speech behavior. That is why people with different cultural backgrounds may have different ways of speaking.

Keywords: Criticism; cross-culture pragmatic; directness-indirectness.

\begin{tabular}{|l|l|l|}
\hline DOI & $:$ & http//dx.doi.org/10.24903/sj.v5i2.496 \\
\hline Received & $:$ & August 2020 \\
\hline Accepted & $:$ & September 2020 \\
\hline Published & $:$ & October 2020 \\
\hline Copyright Notice & $:$ & $\begin{array}{l}\text { Authors retain copyright and grant the journal right of first publication with the } \\
\text { work simultaneously licensed under a Creative Commons Attribution 4.0 } \\
\text { International License that allows others to share the work with an acknowledgement of }\end{array}$ \\
\hline the work's authorship and initial publication in this journal. \\
\hline
\end{tabular}

\section{INTRODUCTION}

Accepting criticism has never been easy; it is one of the speech acts, which is very potential to threaten the hearer's face. Therefore, giving criticism without offending others will always be a challenge. Sun and Hyland (2001) defines criticism as an expression of 
dissatisfaction or negative comment. It means that criticism can also be seen as a negative response or opinions and thoughts that are expressed openly and let others know what is really on our minds about someone or something. T.-M. Nguyen (2005) adds that criticism as an act of illocutionary act whose illocutionary point to give a negative evaluation, or it can be also defined as an expression of dissatisfaction or negative comments to the hearer. This definition shows that criticism is not only an expression of dissatisfaction, but there is an illocution that expects the listener or who receives the criticism to improve or carry out the expected evaluation. Leech (1983) includes criticism under the 'expressive' in his classification. He classifies the speech act into six categories. They are assertive, directive, commissive, 'expressive', declarative, and abrogative. Brown et al. (1987) indicate that speech acts, such as requests, criticisms, and so on, are considered as actions that inherently threaten the face. Spencer-Oatey (2008) also agrees with Brown and Levinson's opinion (Brown et al., 1987) that speech acts are deemed necessary to be handled carefully because many of them can easily threaten rapport. These differences portray their cultural values or their cultural priorities. Therefore, we perceive that culture can distinguish people in using directness or formalities and how expressive they are when delivering speech acts.

In criticizing, people may differ in expressing or conveying it. Ones tend to be careful and sound indirect, while others sound more direct. Spencer-Oatey (2008) defined directnessindirectness as a distinction related to the extent to which the meaning is reflected by words uttered. The more messages are determined by the words used, the more direct the speech, and vice versa. The choice and tendency of a person in determining the strategy and directness level to be used are one of the concerns in pragmatics because the speaker can vary in conveying speech acts. Blum-Kulka (1987, p. 133) said that the level of the directness of criticism with the level of illocutionary transparency requires several attempts to interpret the illocutionary point of this criticism. According to Brown et al. (1987), people's choices of communication style can affect their interactional ethos, and that they might have considerable differences among other socio-cultural groups in this respect. T. T. M. Nguyen (2008) distinguished criticism strategies into two groups, and they are; (1) the 'direct criticism', the strategy which includes negative evaluation, disapproval, expression of disagreement, identification of the problem, statement of difficulties, (2) the 'indirect criticism', they are correction, indicating standard, preaching, request for change, advice about change, a suggestion for change, expression of uncertainty, asking/ presupposing, and other hints. From those classifications, it shows that there are varying patterns in expressing criticism. Some of the criticism strategies sound 'direct', like giving negative evaluation, 
doing refusal and so on, while the other sound more 'indirect', such as giving an advice, asking for change, and many other. All of the various types of criticism patterns mentioned, it can be argued that the direct criticism strategy is more potential to threaten the rapport rather than the indirect one.

Talking about speech acts, including criticism strategies, politeness strategies will never be separated from this discussion. It is because politeness strategy contributes to the way speakers deliver their speech act, including criticism. As Min (2008) argues that criticism is an intrinsically threatening face in Brown and Levinson's terms. It is included in the speech act group that can threaten the positive face of the listener. To make a criticism be more accepted by listeners, speakers tend to reduce the affirmation of criticism by increasing the degree of politeness. It can be said that politeness strategies are often used to reduce the potential threatening rapport that might occur as a result of conveying criticism. Leech (1983) described that politeness levels could be increased by using a more indirect type of illocution, and this is an option for speakers when delivering speech acts. And Watts (2003) points out that in different cultures, politeness can be manifested and understood in different ways through verbal and nonverbal behavior. The view of social norms refers to the normative view of politeness which is seen as a social standard of behavior in any society. The view of social norms assumes social standards are similar to discernment politeness in the sense that they refer to the use of standards in social settings. Watts et al. (2008) also asserted Lakoff's statement that politeness is developed by societies to reduce friction in personal interaction.

As what the researcher found that there are many various patterns of criticism reflected in the food review content delivered by YouTubers from Korea and America, which became the subject of this research, later on, one of the most obvious difference is their directness level in expressing criticism, one sounds indirect, while the other sounds are more direct. Hymes (1964) stated that people in different countries speak differently. Not only because they have different linguistic codes, but also because they use their codes differently. Since differences in ways of speaking between people who have different cultural backgrounds, misinterpretations may occur, and people easily get offended or even stereotyping one another. Therefore, this study was conducted. By using a cross-cultural pragmatics approach, this study tried to observe the diversity of people in delivering the speech act of criticism, and also to answer whether their cultural background influence their speech behavior or not.

A study of directness level of speech acts has already widely done by many researchers, such as Abuarrah et al. (2013) work which examines the directness level of request strategy between Palestinian Arabic and British English, Karatepe (2016) with the study of the 
indirectness level of requests in complaint letters, and also Ogiermann (2009) that analyses the indirectness request of English, German, and Polish. The speech acts of criticism became the focus of the discussion of Farnia (2015) research which examines the criticism among Persian native speakers of various situations that are set to determine the use of criticism strategies often used. This paper focuses on the speech act of criticism as well, but more emphasis on a comparison between Koreans and Americans who have different speech behavior. The main purpose of this study is to observing and comparing speech act patterns, especially the criticism strategy chosen by Korean and American YouTubers in reviewing food. Besides, this study also intended to investigate the role of their cultural background in choosing that strategy. With the hope that this research can provide a better understanding of the diversity of society in using language so that it can reduce the potential for conflict and maintain harmony in social life.

\section{METHOD}

The sample was chosen based on the focus of this study; they are Korean and American YouTubers who have food review content. To narrow the sample, the researcher decided only to observe YouTubers who review Indonesian food, considering that recently many YouTubers create content about Indonesian food, so that it easier for the researcher to collect the data needed.

Table 1. Korean YouTubers

\begin{tabular}{lllll}
\hline Channel & \multicolumn{1}{c}{ Title } & \multicolumn{1}{c}{ Participant } & \multicolumn{1}{c}{ Date } & \multicolumn{1}{c}{ Duration } \\
\hline Noona & Kripik Unik Khas Indonesia & 3 Korean men, 1 & March 16, & $10: 02$ \\
Rosa & & Korean women & 2020 & minutes \\
Hari Jisun & $\begin{array}{l}\text { Oleh-oleh Indonesia yang Bikin Teman } \\
\text { Indonesia Melongo! \# 1 }\end{array}$ & 5 Korean women & June 4, 2019 & $\begin{array}{l}10: 05 \\
\text { minutes }\end{array}$ \\
& & & & \\
Rosakis & Reaksi Orang Korea Snack Indonesia/ & 2 Korean women & December 23, & $9: 39$ \\
& Mukbang Indonesian Snack & & 2018 & minutes \\
\hline
\end{tabular}

Table 2. American YouTubers

\begin{tabular}{|c|c|c|c|c|}
\hline Channel & Title & Participant & Date & Duration \\
\hline THE FLEPT & $\begin{array}{l}\text { American's try Indonesian Snack/ Universal } \\
\text { Yums Unboxing/ Snacks Haul Taste Test }\end{array}$ & $\begin{array}{l}1 \text { American } \\
\text { man } \\
1 \text { American } \\
\text { woman }\end{array}$ & $\begin{array}{l}\text { March 22, } \\
2019\end{array}$ & $\begin{array}{l}15: 08 \\
\text { minutes }\end{array}$ \\
\hline stuff and things & $\begin{array}{l}\text { American Try Snacks from Indonesia: } \\
\text { STUFFandTHINGS Eats }\end{array}$ & $\begin{array}{l}1 \text { American } \\
\text { man } \\
1 \text { American } \\
\text { woman }\end{array}$ & $\begin{array}{l}\text { December } \\
07,2016\end{array}$ & $\begin{array}{l}29: 28 \\
\text { minutes }\end{array}$ \\
\hline BuzzFeedVideo & American Taste Test Indonesian Food & $\begin{array}{l}4 \text { American } \\
\text { men } \\
4 \text { American } \\
\text { women }\end{array}$ & $\begin{array}{l}\text { March 14, } \\
2015\end{array}$ & $\begin{array}{l}2: 55 \\
\text { minutes }\end{array}$ \\
\hline
\end{tabular}


Data needed in this research is oral data in which the data is obtained through a speech delivered by Korean and American YouTubers. The methods and techniques in collecting data are done by watching and taking notes. The first step is selecting three Korean YouTubers and three American YouTubers who make Indonesian food review content. Second, one video from each chosen YouTubers were watched and took notes every expression of criticism that emerged. In the third step, the researcher analyzed all data collected to compare the directness levels of criticism they conveyed. This study also intended to know whether their speech behavior is influenced by their cultural background or not. All references that provide information about these two cultures, American and Korean culture, are used as references to answer that question by implementing a cross-cultural perspective.

\section{FINDINGS}

According to T. T. M. Nguyen (2008) criticism strategies divided into two groups, they are; (1) the 'direct criticism', the strategy which includes negative evaluation, disapproval, expression of disagreement, identification of the problem, statement of difficulties, (2) the 'indirect criticism', they are correction, indicating standard, preaching, request for change, advice about change, a suggestion for change, expression of uncertainty, asking/ presupposing, and other hints. Below are the findings of this study, where the number of frequencies and percentages of Korean and American YouTuber criticisms are displayed.

Table 3. The general distribution of criticism strategy types on videos of American and Korean YouTubers

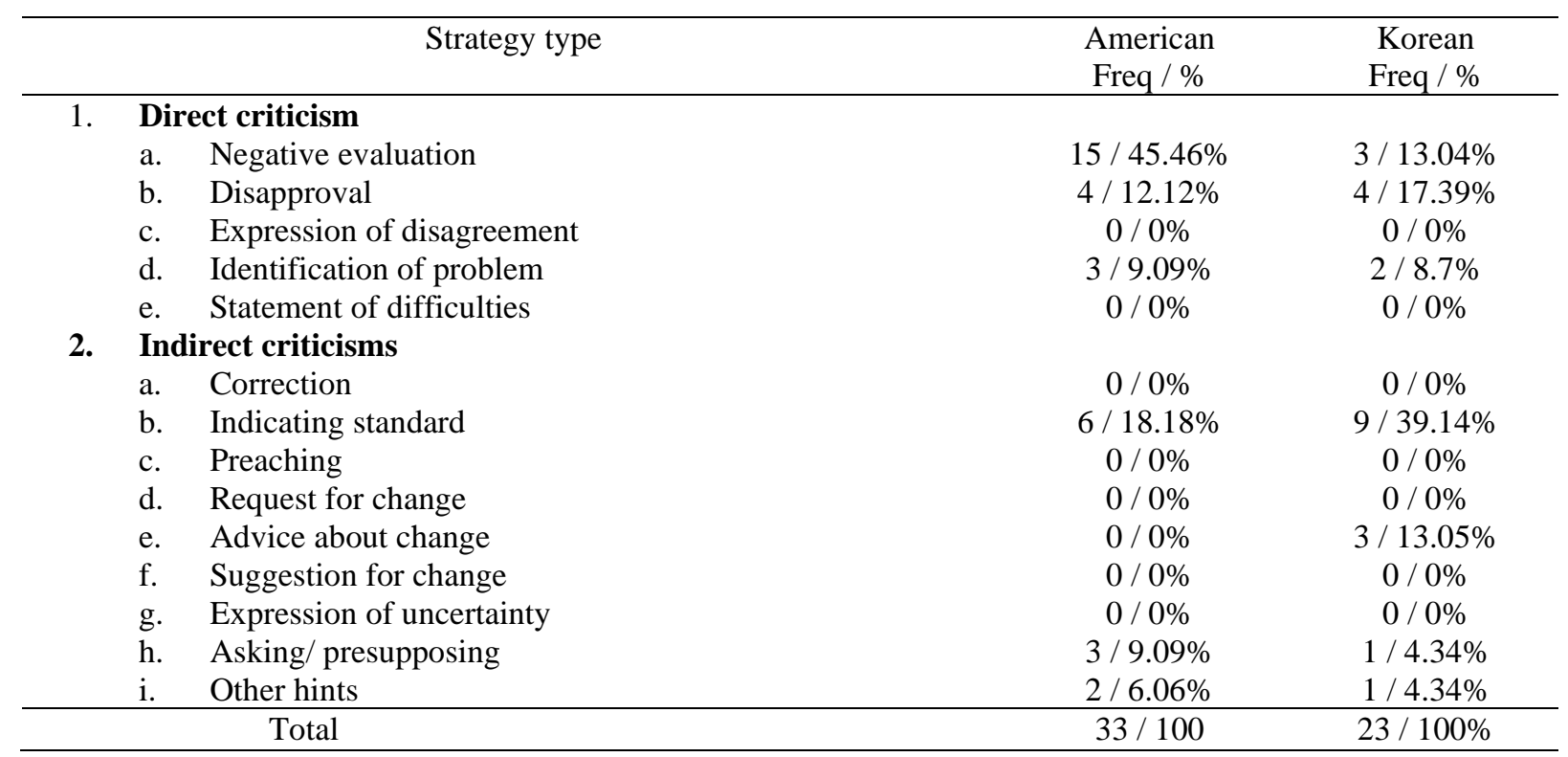

Table 3 shows that in general, American YouTubers commonly used direct criticism strategies, while Korean YouTubers tend to use the indirect one. The negative evaluation 
$(45.46 \%)$ was the strategy that most frequently used by American YouTubers among the other strategies. And the indicating standard (39.14\%) was the strategy most frequently used by Korean YouTubers, which is an indirect one. Sometimes, Americans used indirect strategies as well, and the indicating standard (18.18\%) has become the strategy that appeared the most. The direct strategies were also found in Korean YouTuber's speech, and the disapproval strategy was the direct strategy that appeared the most $(17.39 \%)$. Take a look at the chart below to see a significant difference between Korean and American YouTuber utterances.

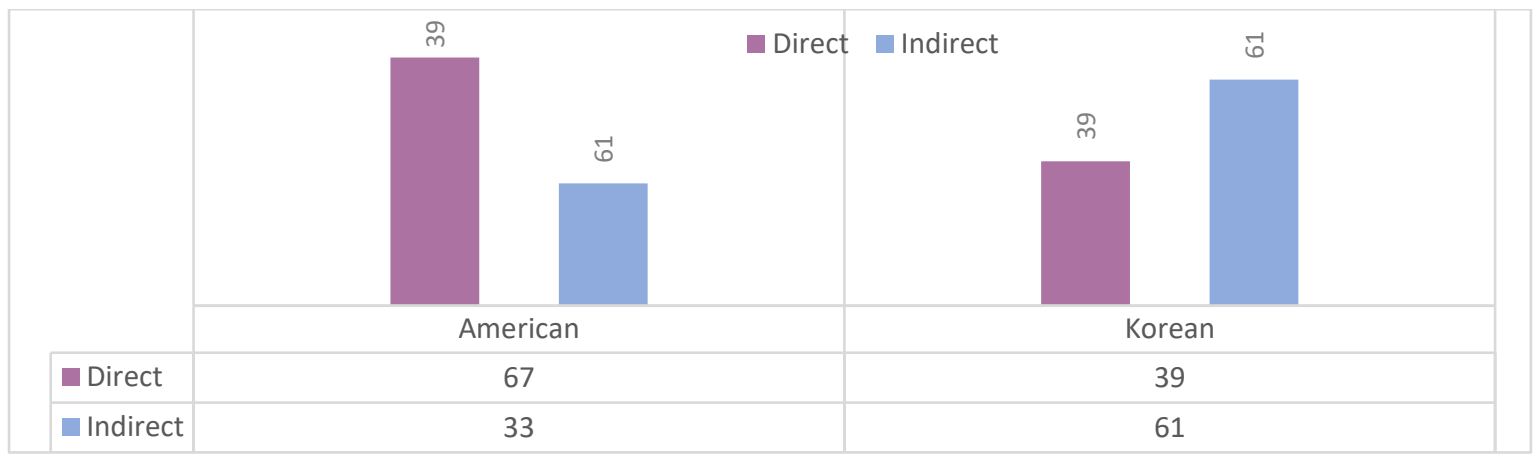

Figure 1. The comparison between the two American and Korean YouTubers choosing criticism strategies

\section{DISCUSSION}

According to the data in table 3 , the choice of the direct criticism strategy was commonly used by American YouTubers rather than the indirect one. And the most emerged direct criticism strategy was the 'negative evaluation'. The negative evaluation patterns tend to be blatantly in giving a bad judgment without adding other components that serve to soften the speech act, such as adding the phrase "I personally...", "in my opinion ...", etc. Below are examples of Korean and American Youtuber utterances in using the negative evaluations:

- Negative evaluation strategy

American: It tastes like Styrofoam with an after taste of fish

Korean: It tastes like chocolate flavored medicine

And compare with American YouTubers utterances, Koreans prefer to do refusal rather than give a bad comment to something they don't like. It can be seen from the number of the disapproval strategy that appears more often than the negative evaluation. This contrasts with the Americans who used the negative evaluations the most among other direct strategies. Now take a look at the example of direct criticism using the disapproval strategy conveyed by Korean and American YouTubers below:

- Disapproval strategy

American: I don't like it 
Korean: It's hard to eat it again

Table 3 also represents that Korean YouTubers commonly used indirect criticism strategies. And the indicating standard strategy is the most emerged among other strategies. While in Americans, this strategy is in the second position after the negative evaluation. This strategy provides standards with the emphasis on personal opinion to weaken the speech act and reduce the impression of giving an outright negative evaluation or rejection. As elicitations below:

- Indicating standard

American: I feel like this is not as much chocolate as promised

Korean: I like it, but to me, it's too spicy and too salty. The taste is very strong.

Identification of problem strategy was also found in both Korean and American Youtubers utterances in expressing criticism. This identifying problem strategy can be a complaint statement which might tend to be direct and easy to threaten the face if we express it too bluntly. Below are some examples:

- Identification of problem

American: Every single one of these things has been harder than I thought

Korean: This is stuck between my teeth

Asking/ presupposing strategy is one of the indirect criticism strategies used by both Korean and American YouTubers, with the appearance of 9.09\% in American utterances, and $4.34 \%$ in Koreans. This strategy was used to express dissatisfaction by conveying their expectation.

- Asking/ presupposing

American: I would prefer to be just chocolate

Korean: If it's more liquid, it will taste good

As mentioned before, this research was conducted not only to perceive the different patterns of criticism delivered by Korean and American YouTubers but also to investigate whether the speech behavior they exhibited is related to their cultural background or not. Wierzbicka (2003) emphasizes that all cultures try to maintain a good relationship among people in social life. However, every culture has a different mindset and way of achieving these goals. These different interpretations are reflected in their different ways of speaking, known as 'ethnographies of speaking'. The finding displayed in the table above shown that the level of the directness of criticism used by Korean and American YouTubers was not the same. Zhang (2001) concurs with DeCapua (1989) argumentation (1989) that the concept of directness is closely related to the idea of speech acts that threaten faces and politeness 
strategies. The directness level can refer to how strong or aggressive the speech act or utterances that can threaten the face of the hearer. Wierzbicka (1985) stated that the evaluation of the realization of certain speech acts in terms of directness and politeness varies across cultures and depends on social and cultural values and norms. Wierzbicka Wierzbicka (2003, p. 61) also added that the notion of politeness is known in every culture, but the practical realization of the phrase "be polite" differs from one culture to another.

The directness level of the speech acts of criticism that was conveyed by American YouTubers is quite related to their socio-cultural values. Wierzbicka (2003) explained that in Anglo-American culture, people could freely express their feelings or say what they want to say, but they are not expected to be too 'blunt' when conveying them. For this culture, it is important to acknowledge everyone's right for personal freedom and to use their right to selfexpression, as long as it does not violate the autonomy of others, because of that individualism centered culture. Watts (2003) also explained that American politeness usually relies on personal autonomy and how people maintain the etiquette of the conversation. As a result, every individual is usually given more rights to choose which politeness strategies they will use to maintain each other's autonomy in the conversation. Song (2014) stated that, generally, politeness in American culture is related to social etiquette, and it is used to avoid conflicts, and their characteristics tend to be individualistic and rational.

Wierzbicka (2003) added that in white Anglo-American culture, the main emphasis was not on preventing displeasure, or spontaneous and uninhibited self-expression, but rather on personal autonomy for everyone, on non-imposition, and so on. Therefore, this culture encourages people to say freely at the right time what they think or what they want to say, as long as it does not violet other personal autonomy. The concept of American culture can be represented as follows; Anyone can say: "I want this", but they cannot say: "You have to do this because I want it" (Wierzbicka, 2003, p. 80). From what experts have explained about American culture, we can see that there is relevance to the behavior exhibited by American YouTubers. The fact that they generally use a direct strategy in expressing criticism is related to their culture that upholds the importance of recognizing everyone's right and personal autonomy, and also encouraging everyone to express their feelings and opinions. Therefore, the speech behavior that American Youtubers expressed can be assumed to be the result of the influence of their cultural background.

If American YouTubers are assumed to use more direct criticism rather than the indirect one, contrary to the Korean YouTuber, which indicates that the indirect strategy was the most frequently emerge. According to Hofstede's study (I. Lee, 2005) Korea, even more than 
Japan, is a society that positions harmony and consensus as to the main goal. Maintaining harmony and avoiding confrontation is the norm they obey, and the nature of communication typically high-context. Song (2014) stated that Korean culture is very collectivist. They tend to be communal, hierarchical, respectful, formal, and emotionally oriented. Shin (2017) also adds that politeness in Korean culture is generally applied through appreciating politeness, harmony, indirectness, and modesty.

In line with the table above which shows that the use of disapproval and negative evaluation appears less in Korean YouTuber utterances than in American ones, this phenomenon is related to what C. Y. Lee (2012) explained that Korean People tend to do things with the respect of others' opinions and feelings. They like to avoid saying "no" to avoid hurting others' Kibun - considering that this culture places harmony as something very important to be maintained. Chaney and Martin (C. Y. Lee, 2012) defined Kibun as mood or feeling of balance and good behavior. According to Kim (in C. Y. Lee, 2012). Korean life in social and business is influenced by Confucianism. Confucianism is an ancient Chinese mindset that has spread to much of East Asia. A way of life of Kung Fu-Tzu, a teacher known in Western countries as Confucius who lived in China around 500 BC. C. Y. Lee (2012) added that according to Cho and Yoon, Confucianism emphasizes duty, loyalty, honor, respect for age and seniority, and sincerity. And in general, Confucianism has influenced the society of South Korea in many aspects, such as their status relations, social contacts, and so on.

In the process of observing data, the researcher also found that Korean YouTubers, in certain situations, gave a silent reaction when reviewing food. However, their body language clearly is shown as dislike or rejection. This behavior might be explained by C. Y. Lee (2012) about the Nunchi. Nunchi can be translated as an eye measure. In other words, Nunchi is a person's ability to understand other people's Kibun through their eyes. C. Y. Lee (2012) added that Korean people tend to express their different opinions or feelings by giving positive or ambiguous answers. However, people are expected to be able to read their nonverbal language or their body language to understand the answers they mean. Southerton (in C. Y. Lee, 2012) also suggests that people need to learn other people's non-verbal language and body language to understand the true meaning of what they are saying. Nunchi is like the sixth sense, the ability to see visual cues to understand what the person is saying.

The behavior of Korean people who often avoid outright rejection can also be related to another key principle of their culture, namely Inhwa. Alston (in C. Y. Lee, 2012) defined Inhwa as harmony. As a collectivist society, the consensus is an important element in 
maintaining harmony in their social life. Inhwa is the result of Confucian belief, which emphasizes harmony between communities so that Korean people would like to give positive answers and avoid or are reluctant to give outright rejection. They do not want to ruin the harmonious environment by giving negative answers or rejecting others to cause face loss.

In conclusion, the direct criticism used by Korean Youtubers is less than the direct criticism found in American YouTuber's utterances, and they also tend to avoid blatant confrontations, such as giving negative evaluations, making rejections, etc. This behavior is quite relevant to what some experts describe Korean cultural norms as discussed above. Many experts described that Korean culture tends to maintain harmony by avoiding confrontation and restraint to express feelings and opinions bluntly. So, it makes sense that the speech behavior they show is considered a result of the influence of their cultural norms.

\section{CONCLUSION}

The results of this study indicate that there are significant differences in the level of direct criticism used by Korean and American YouTubers in reviewing food. Based on the data collected shows the direct criticism strategy appeared more frequent in American YouTuber's utterances, whereas in Korea appeared less. This study also finds out that the speech behavior delivered by both American and Korean Youtubers were related to their cultural norms. Where Anglo-American culture according to Wierzbicka (2003) acknowledge everyone's right and personal autonomy and encourage everyone to express their personal feelings and opinions freely as long as it does not violate the autonomy of others. Whereas Korean culture as Hofstede's study (I. Lee, 2005) is considered to tend to avoid confrontation to maintain harmony, due to harmony and consensus are their ultimate goals in social life. Finally, from all the discussion above, it can be concluded that culture takes a significant part in shaping one's speech behavior. That is why people with different cultural backgrounds may have different ways of speaking.

\section{REFERENCES}

Abuarrah, S., Lochtman, K., \& Lutjerhams, M. (2013). Cross-cultural pragmatics requests' use of strategy and level of directness in Palestinian Arabic and British English. AnNajah University Journal for Research-B (Humanities), 27(5), 1109-1144. https://journals.najah.edu/article/932/

Blum-Kulka, S. (1987). Indirectness and politeness in requests: Same or different? Journal of Pragmatics, 11(2), 131-146. https://doi.org/10.1016/0378-2166(87)90192-5

Brown, P., Levinson, S. C., \& Levinson, S. C. (1987). Politeness: Some universals in language usage. Cambridge University Press. 
DeCapua, A. (1989). An analysis of pragmatic transfer in the speech act of complaints as produced by native speakers of German in English. Columbia University.

Farnia, M. (2015). A Sociopragmatic Analysis of the Speech Act of Criticism by Persian Native Speakers. International Journal of Humanities and Cultural Studies, 2(3), 305323.

Hymes, D. (1964). Introduction: Toward ethnographies of communication1. American Anthropologist, 66(6_PART2), 1-34. https://doi.org/10.1525/aa.1964.66.suppl_3.02a00010

Karatepe, $\ddot{Y}$. (2016). Indirectness in requests in complaint letters to the higher institution by Turkish EFL students. Procedia - Social and Behavioral Sciences, 232, 354-361. https://doi.org/10.1016/j.sbspro.2016.10.050

Lee, C. Y. (2012). Korean culture and its influence on business practice in South Korea. The Journal of International Management Studies, 7(2), 184-191. https://doi.org/10.1.1.383.7473

Lee, I. (2005). The law and culture of the apology in Korean dispute settlement (with Japan and the United States in mind). Michigan Journal of International Law, 27(1), 1-53.

Leech, G. N. (1983). Principles of pragmatics. Longman.

Min, S.-C. (2008). Study on the differences of speech act of criticism in Chinese and English. US-China Foreign Language, 6, 74-77.

Nguyen, T.-M. (2005). Criticizing and responding to criticism in a foreign language: A study of Vietnamese learners of English. Department of Applied Language Studies and Linguistics.

Nguyen, T. T. M. (2008). Modifying L2 criticisms: How learners do it? Journal of Pragmatics, 40(4), 768-791. https://doi.org/10.1016/j.pragma.2007.05.008

Ogiermann, E. (2009). Politeness and in-directness across cultures: A comparison of English, German, Polish and Russian requests. Journal of Politeness Research. Language, Behaviour, Culture, 5(2). https://doi.org/10.1515/JPLR.2009.011

Shin, M. (2017). An exploratory study on politeness strategies in requests by Korean learners of English and American English speakers. In TESOL Working Paper Series (No. 15).

Song, S. (2014). Politeness in Korea and America: A comparative analysis of request strategy in English communication. Korea Journal, 54(1), 60-84. https://doi.org/10.25024/kj.2014.54.1.60

Spencer-Oatey, H. (2008). Culturally speaking culture, communication and politeness theory. Bloomsbury Publishing.

Sun, J., \& Hyland, K. (2001). Disciplinary discourses: Social interactions in academic writing. TESOL Quarterly, 35(2), 344. https://doi.org/10.2307/3587657

Watts, R. J. (2003). Politeness. Cambridge University Press.

Watts, R. J., Ide, S., \& Ehlich, K. (2008). Politeness in language studies in its history, theory and practice. Mouton de Gruyter.

Wierzbicka, A. (1985). Different cultures, different languages, different speech acts. Journal of Pragmatics, 9(2-3), 145-178. https://doi.org/10.1016/0378-2166(85)90023-2

Wierzbicka, A. (2003). Cross-cultural pragmatics: The semantics of human interaction. Mouton de Gruyter.

Zhang, D. (2001). The speech act of complaining: A cross-cultural comparative study of Chinese and American English speakers [Iowa State University]. https://lib.dr.iastate.edu/rtd/16213/ 